\title{
The Effects of International Accounting Standardization on Business Performance: Evidence from Hungary
}

\author{
Gyorgy Csebfalvi ${ }^{1}$ \\ ${ }^{1}$ Department of Business Information System, University of Pecs, Pecs, Hungary \\ Correspondence: Gyorgy Csebfalvi, Department of Business Information System, Faculty of Business and \\ Economics, University of Pecs, PO box 80, Street of Rakoczi, City of Pecs H-7622, Hungary. Tel: \\ 336-36-72-501-599. E-mail: cseb@ktk.pte.hu
}

\author{
Received: January 18, 2012 Accepted: March 6, $2012 \quad$ Published: May 1, 2012 \\ doi:10.5539/ijbm.v7n9p20 URL: http://dx.doi.org/10.5539/ijbm.v7n9p20
}

\begin{abstract}
The purpose of this study was to measure the differences between national rules and the international standards, evaluating and analyzing their effects on the shifting business environment. The unified business information system will lead to new types of analysis and data, furthermore with the possible integration of new indicators from the business environment of certain countries. The results show that those businesses which have adopted international standards achieved higher and statistically significant positive coefficients than those following local accounting rules. Companies which had adopted accounting standards also provided higher quality and value relevant accounting information systems. As a further consequence of international accounting standards adoption, corporate policy and requirements became gradually more clear and transparent - in the same way as the application and implementation of the standards became more user-friendly.
\end{abstract}

Keywords: accounting standards, unified business information system, shifting environment, economic effects, value based management, Hungary

\section{Introduction}

The present paper is organized as follows. After the background information this section shows the content, scope and importance of this research. The next section reviews the related international literature. Section 3 describes the research methodology and the results. Finally, concluding remarks and discussion are presented in Section 4.

Nowadays, especially during the current global financial crisis, companies in Hungary are striving desperately to remain competitive and achieve sustainable levels of economic development. The highly competitive environment requires companies to create a clear business strategy, and accounting has to be part of this strategy since it helps individual enterprises to achieve their strategic objectives. International accounting standards are new global methods to develop unified business information systems and they are able to harmonize financial regimes both world-wide and in Hungary also. The increased globalization of markets, the complexity of commercial trading and the concentration of business in global competition have led to a still greater need for international harmonization.

With increasing globalization of the marketplace, international investors need access to financial information based on harmonized accounting standards and procedures. Investors constantly face economic choices that require a comparison of financial information. Without harmonization in the underlying methodology of financial reports, real economic differences cannot be separated from alternative accounting standards and procedures. Harmonization is used as a reconciliation of different points of view, which is more practical than uniformity, which may impose one country's accounting point of view on all others. Organizations, private or public, need information to coordinate its various investments in different sectors of the economy. With the growth of international business transactions by private and public entities, the need to coordinate different investment decisions has increased.

Since in case such multinational companies like Daimler Chrysler owning more than 900 subsidiaries, operating on 5 continents in more than 60 countries, the published financial results according to international standards is 1.5 times of the one according to German accounting standards. If earning after taxation (EAT) - deducted actual 
tax burdens - according to US GAAP is taken as 100 percent, due to differences between national accounting standards, EAT would be 25\% more in UK, 3\% less in France, 23\% less in Germany and 34\% less in Japan (Barth et al., 2007).

\section{Previous Related International Literature Review}

International accounting literature provides evidence that accounting quality has economic consequences, such as costs of capital (Leuz and Verrecchia, 2000), efficiency of capital allocation (Bushman and Piotroski, 2006) and international capital mobility (Guenther and Young, 2008). The International Accounting Standards Board (IASB) has planned to develop a unified and understandable global accounting convergence (Easton, 2006), and the IASB's plan has resulted in more than 100 countries world-wide now requiring, permitting or adopting International Financial Reporting Standards (IFRS) (Epstein, 2009). This growing acceptance of IFRS has also influenced emerging economies (Ball et al., 2003). Beke (2010a, p.23) asserted that "the purpose of the use of international accounting information systems is that similar transactions are treated the same by companies around the world, resulting in globally comparable financial statements". These findings have led many authors to conclude that global comparability will be driven by factors other than the accounting standards. In particular, most authors point to either regulatory oversight or capital market pressures (Burgstahler et al., 2006).

Researchers have suggested that the best approach to assessing the applicability of IFRS is to evaluate the convergence process in emerging markets (Jones and Higgins, 2006, Cordazzo, 2008). However, the process of adoption has been the subject of limited research, since researchers themselves have suggested that it would be better to use national case studies to analyze the adoption of IFRS in individual nations. Examples of this are Callao-Jarne-Lainez (2007) in Spain, Cormier-Demaria-Lapointe-Teller (2009) in France, Lantto and Sahlström (2009) in Finland, Iatridis and Rouvolis (2010) in Greece, Peng and Smith (2010) in China and Beke (2010b) in Hungary also.

The research undertaken in the form of national case studies will develop guide-lines on best practice in the implementation of IFRS in order to assist developing countries and countries with economies in transition to succeed in their efforts to harmonize their national accounting rules and practice with international requirements

Earlier literature shows that the level of the capital market orientation of the financial environment also follows the differences in accounting systems internationally. Examples of this are found when the Common Law accounting systems of the USA and the UK are compared with Code Law-based systems of many Continental European countries (see, for example, La Porta, 1998).

Earlier studies show that, in Code Law countries (e.g., in Europe) the capital provided by banks tends to be more important than in Common Law countries (e.g., the USA and Canada) where firms are mainly financed by a large number of private investors (Zeff, 2007). Therefore, information asymmetry between capital providers and the company is likely to be resolved in Code Law countries by providing accounting information to the capital providers by means of high-quality, public financial reporting (e.g. Beke, 2011a).

Previous studies also show that the adoption of IFRS improves the accounting quality of publicly traded companies in Europe (Daske and Gebhardt, 2006). Overall, the adoption of IFRS seems to benefit investors, especially in countries which resemble Code Law clusters and where the information needs of investors were not the primary interest of standards setters.

Additionally, many papers examine the properties of business information across different accounting regimes. Overall, these studies indicate that similar accounting methods are applied very differently around the world. However, Beke (2011b, p.176) remarked that "the unified business information system will probably lead to new types of analysis and data - with the possible additional integration of new indicators from the practice of certain countries". Accounting standard-setters and regulators around the globe are planning to harmonize accounting standards with the goal of creating one set of high-quality rules to be applied world-wide (Whittington, 2008).

\section{Methodology}

The purpose of this study was to measure the differences between national rules and the international methods, evaluating and analyzing their effects on the business environment. This survey also includes information on how international accounting standards have been affected by the global economic crisis. To examine decisions made by companies to adopt IFRS, we created a sample comprising Budapest Stock Exchange (BSE) enterprises who adopted IFRS in Hungary in 2007. For the purpose of research, the pre-adoption period was 2004-2006 and the post-adoption 2008-2010. The final sample consists of 65 companies who adopted IFRSs and 260 Hungarian firms using local accounting rules. The specific samples are of conventional shareholder companies with Hungarian headquarters who employ an average of more than 50 people. 
The financial data are taken from accounts published on the Budapest Stock Exchange and in the Hungarian Business Information database. In our sample, the firms are classified as either 'following international standards' or as 'using national accounting rules". The manufacturing firms have the largest representation in our sample. The study excluded banks, insurances, pensions and brokerages since their accounting measures are not always comparable with industrial sectors. Parameters in the logistic regression models were estimated with maximum likelihood method and the correlations between variables with autocorrelation and multicollinarity.

Basically, we used a qualitative comparative approach, but to identify the results of our research, we elaborated three hypotheses:

$\mathrm{H}_{1}$ : Balance Sheet indices deteriorated - especially in respect of solvency and prosperity after adopting IFRS.

$\mathrm{H}_{2}$ : Heavy losses tend not to be infrequent after IFRS adoption decisions.

$\mathrm{H}_{3}$ : Business management has higher value relevance after the post-adoption period.

\subsection{Accounting Methods and Balance Sheet Effects}

This set of analyses measures how Hungarian enterprises have been affected in terms of business performance by IFRS and how they have adjusted over time (see also Beke, 2011c) The logistic regression models employed are $(1,2)$ :

$$
\begin{aligned}
& R R_{i, t}=a_{0}+a_{1} \text { Size }_{i, t}+a_{2} \text { Dividend }_{i, t}+a_{3} \text { Growth }_{i, t}+a_{4} \text { Profitability }_{i, t}+ \\
& +a_{5} \text { Liquidity }_{i, t} \quad+a_{6} \text { Leverage }_{i, t}+e i_{, t} \\
& P A_{i, t}=a_{0}+a_{1} \text { Size }_{i, t}+a_{2} \text { Dividend }_{i, t}+a_{3} \text { Growth }_{i, t}+a_{4} \text { Profitability }_{i, t}+ \\
& +a_{5} \text { Liquidity }_{i, t} \quad+a_{6} \text { Leverage }_{i, t}+e i_{, t}
\end{aligned}
$$

Where:

$\mathrm{RR}_{\mathrm{i}, \mathrm{t}} \quad=$ dummy variable, indicating the regulatory system,

- $\mathrm{RR}_{\mathrm{i}, \mathrm{t}}=1$, financial numbers are reported by IFRS,

- $\mathrm{RR}_{\mathrm{i}, \mathrm{t}}=0$, financial numbers are reported by National GAAP,

$\mathrm{PA}_{\mathrm{i}, \mathrm{t}}=$ dummy variable, indicating the post-adoption effects.

- $\quad \mathrm{PA}_{\mathrm{i}, \mathrm{t}}=1$, financial numbers are reported by IFRS in 2008

- $\quad \mathrm{PA}_{\mathrm{i}, \mathrm{t}}=0$, financial numbers are reported by IFRS in 2006.

Size: Natural logarithm of market capitalization:

- NAVSH: Net asset value per share

- RESSFU: Reserves to shareholders' funds

Dividend:

- DIVCOV: Dividend cover

- DIVSH: Dividend per share

- DIVYI: Dividend yield.

Growth:

- MVBV: Market value to book value

Profitability:

- EPS:

Earnings per share

- NPM:

Net profit margin

- ROCE:

Return on capital employed

Liquidity:

- CFM: Cash flow margin

- CUR: Current ratio

- OCF: Operating cash flow scaled by total assets

- QUI: Quick ratio

- WCR: Working capital ratio

Leverage :

- DEBTE: Debt to equity

- DSFU: Debt to shareholders' funds

- CGEAR: Capital gearing

$\mathrm{e}_{\mathrm{i}, \mathrm{t}}=$ the error term.

The results of hypotheses $\mathrm{H}_{1}$ are reported in Table 1 . 
Table 1. Accounting method effects

\begin{tabular}{|c|c|c|c|c|}
\hline \multirow[t]{2}{*}{ Denomination } & \multicolumn{2}{|c|}{ Domesticl GAAP-using firms } & \multicolumn{2}{|c|}{ IFRS adopted firms } \\
\hline & Mean & Std. deviation & Mean & Std. deviation \\
\hline DIVSH & 0,0846 & 0,1986 & 0,1557 & 0,2106 \\
\hline DIVYI & 17,5764 & 19,8721 & 22,8705 & 25,4457 \\
\hline MVBV & 5,8152 & 7,8125 & 2,5478 & 8,1547 \\
\hline NPM & $-0,2945$ & 4,5412 & $-0,1031$ & 7,4581 \\
\hline EPS & 0,1987 & 1,0561 & 0,1897 & 1,5061 \\
\hline ROCE & 0,2008 & 0,3051 & $-0,0081$ & 0,6401 \\
\hline $\mathrm{OCF}$ & 3,8812 & 15,4421 & 4,8512 & 16,8041 \\
\hline CUR & 1,9911 & 6,9105 & 2,9814 & 3,1125 \\
\hline CFM & 0,8029 & 2,3126 & $-0,0408$ & 1,5974 \\
\hline DEBTE & 1,9843 & 2,3566 & 2,3099 & 2,1577 \\
\hline CGEAR & 0,3454 & 0,2325 & 0,8714 & 0,3115 \\
\hline DSFU & 0,3258 & 0,1353 & 0,5469 & 0,8540 \\
\hline
\end{tabular}

(Source: Author's own constructions)

It can be seen in Table 1 that the average index of dividend per share (from earnings after tax) is higher at companies which had already adopted IFRS than in others. However, the relative average value (DIVYI) contains a high deviation (the deviation value is almost 30 in respect of companies using IFRS).

The companies applying the National Accounting Rules earn more than double $(5,8152)$ in terms of growth (measured by market value to historical value of assets) than do other firms. In this sense the IFRS-adopting companies' average index is much lower.

The companies examined had a negative average net profit value (loss) in both groups in the period covered, although the return on equity and the average return on capital employed gave better results for National Accounting Rules users. The latter index showed a declining tendency $(-0,0081)$ at companies which adopted the IFRS.

The National Accounting Rules-using companies' average indices measuring solvency (OCF, CUR, CFM) and leverage were higher than the others. Cash Flow, for instance, decreased $(-0,0408)$ at IFRS-adopting companies, although around the relative average value of Operating Cash Flow on assets the deviation is quite high (between 15 and 17). As the indebtedness of companies using National Regulations was lower, the leverage indices (DEBTE, CGEAR, DSFU) were better than in those companies which had adopted IFRS.

To summarize, we can state that Balance Sheet indices deteriorated especially regarding solvency and prosperity after the adoption of IFRS.

\subsection{Accounting Methods and P\&L Effects}

This part of our research examined whether firms determine small positive profits rather than large losses. (see Beke, 2011d) .Our analysis employed the next model (3):

Where:

$$
\begin{aligned}
R R_{i, t}=a_{0} & +a_{1} \text { Profitability }_{i, t}+a_{2} \text { Dividend }_{i, t}+a_{3} \text { Growth }_{i, t}+a_{4} \text { Size }_{i, t}+ \\
& +a_{5} \text { Liquidity }_{i, t}+a_{6} \text { Leverage }_{i, t}+a_{7} \text { SP }_{i, t}+a_{8} L L_{i, t}+e_{i, t}
\end{aligned}
$$

$\mathrm{SP}_{\mathrm{i}, \mathrm{t}}=$ dummy variable indicating a measure of small positive profits.

$\mathrm{SP}_{\mathrm{i}, \mathrm{t}}=1$ if net profit scaled by total assets is between 0 and 0.01 ,

$\mathrm{SP}_{\mathrm{i}, \mathrm{t}}=0$ otherwise.

$\mathrm{LL}_{\mathrm{i},} \quad$ = dummy variable indicating a measure of timely loss recognition.

$\mathrm{LL}_{\mathrm{i}, \mathrm{t}}=1$ if net profit scaled by total assets is less than -0.20 ,

$L_{\mathrm{i}, \mathrm{t}}=0$ otherwise.

The results of model (3) are reported in Table 2. 
Table 2. Small profit or large losses

\begin{tabular}{lcc}
\hline Denomination & IFRS adopted firms & Domestic GAAP- using firms \\
\hline SP & $-1,194^{* *}$ & 0,451 \\
LL & $2,581^{*}$ & 1,324 \\
\hline
\end{tabular}

Sourse: Author's own constructions

$*$ at $10 \%$ level significance, $* *$ at $5 \%$ level significance..

The data in the Table 2 prove that the companies which had already adopted IFRS were less willing to hide profit in the P\&L. Account when it was low, and by doing so, the probability of reporting a small profit (SP) was significantly negative $(-1,194)$ in their case.

Further, we can state that neither did they did tend to hide a large loss. The latter statement is a consequence of the positive and high value of the coefficient of LL $(2,581)$. It is specific for National Accounting Rules-using companies to favor reporting smaller profits $(0,451)$ and avoid large losses being reported in P\&L Account which is possible when using accrual-based accounting.

\subsection{Accounting Methods and Value Relevance}

Prior researches indicates that the standardization based accounting systems tend to realize higher quality and value relevance (e.g. Hung and Subramanyam, 2007; Tarca, 2004; Tandeloo and Vanstraelen, 2005). We were wondered if is it the same case in Hungary and we tested it with following hypothesis:

3.3.1 The first value relevance test is an OLS regression of share price on book value per share and net profit per share (4)

Where:

$$
P_{i, t}=a_{0}+a_{1} B V P S_{i, t}+a_{2} N P P S_{i, t}+e_{i, t}
$$

$\mathrm{P}_{\mathrm{i}, \mathrm{t}}=$ Total market value of equity deflated by number of shares outstanding,

BVPS $_{i, t}=$ Total book value of equity deflated by number of shares outstanding,

$\mathrm{NPPS}_{\mathrm{i}, \mathrm{t}}=$ Total net profit deflated by number of shares outstanding.

3.3.2 The second value relevance test is an OLS regression of profits on stock returns (5)

$$
N P P_{i, t}=a_{0}+a_{1} A R_{i, t}+e_{i, t}
$$

Where:

$\mathrm{NPP}_{\mathrm{i}, \mathrm{t}}=$ Net profit divided by beginning of year share price,

$\mathrm{AR}_{\mathrm{i}, \mathrm{t}} \quad=$ Annual stock return at year-end.

3.3.3 The third value relevance test measured the association between IFRS-based book value and net profit figures, then stock returns (6)

$$
A R_{i, t}=a_{0}+a_{1} B V P S_{i, t}+a_{2} B V C H A_{i, t}+a_{3} N P P S_{i, t}+a_{4} N P C H A_{i, t}+e_{i, t}
$$

Where:

BVCHAi,t = Variable indicating the change in corporate book value following the transition to IFRS,

NPCHAi,t = Variable indicating the change in corporate net profits following the transition to IFRS.

The results of value relevance models are summarized in Table 3.

Table 3. Accounting methods and value relevance

\begin{tabular}{lrr}
\hline Denomination & \multicolumn{2}{c}{ Coefficients } \\
\cline { 2 - 3 } & Domestiv GAAP-using firms & IFRS adopted firms \\
\hline NPPS & $2,041^{* *}$ & $3,025^{* *}$ \\
BVPS & $0,547^{* *}$ & $1,354^{* *}$ \\
AR & $2841,145^{* *}$ & $3694,124^{*}$ \\
BVCHA & $0,1941^{* *}$ & $0,2941^{*}$ \\
NPCHA & $0,0182^{* *}$ & 1,3541 \\
$\mathrm{R}^{2}$ & 0,689 & 0,799 \\
\hline
\end{tabular}

*Statistical significance at 10\% level,

**Statistical significance at $1 \%$ level.

(Source: Author's own construction) 
Our $\mathrm{H}_{3}$ assumption, namely that the information system of companies who adapted IFRS shows a higher value relevance than other national accounting rules-user companies, is proved by the data of Table 3 .

The first test of value relevance gave a result for earnings after tax/share (EPS) coefficient $(3,025)$ and for book value of equity/share $(1,354)$ which is significantly (at $1 \%$ ) positive and higher at IFRS-adopting companies than at others. These companies also had more profitable, higher correlation coefficients of financial indices $\left(R^{2}\right.$ $=0,799$ ).

The second test of value relevance gave similar results since the coefficient of Return on Equity (ROE) is also significantly (at $10 \%$ ) positive and higher $(3694,124)$ at companies which have already adopted IFRS.

The coefficient of Book Value Change $(1,3541)$ produced turned out significantly more positive at IFRS-adopting companies according to the third test of value relevance. These results obviously prove that the companies which adopted IFRS have an orientation towards a reporting policy based on greater reliability and more realistic evaluation. However, the index presenting the change of Net Profit (NPCHA) was also positive (but not significantly) at these companies $(1,3541)$.

\section{Conclusion}

In today's business environment, companies need to take every opportunity they can to remain competitive. Global competition, rapid innovation, entrepreneurial competitors, and increasingly demanding customers have altered the nature of competition in the marketplace. This new competitive environment requires companies to be able to create value for their customers and to differentiate themselves from their competitors through the formulation of a clear business strategy. Business strategy must be supported by appropriate organizational factors such as an efficient manufacturing process, organizational design and harmonized accounting information systems also.

We noted that the Balance Sheet indices deteriorated, especially regarding solvency and prosperity after adoption of IFRS. The results show that those businesses which have adopted international standards achieved higher and statistically significant positive coefficients than did those following local accounting rules. We found that larger firms, those with more leverage, higher market capitalization and substantial foreign sales, were more likely to have adopted international accounting standards. Among these firms, lower profits are declared less frequently possibly indicative of the quality of earnings management. Companies which had adopted IFRS also provided higher quality and value relevant accounting information systems. As a further consequence of IFRS adoption, corporate policy and requirements became gradually more clear and transparent - in the same way as the application and implementation of the standards became more user-friendly.

After the measuring these economic effects of accounting standardization on business management and achieving some results the author decided that we have to continue this analyzing process using interdisciplinary methods also, because it can be reach the whole real picture of globalized unified business information systems.

\section{References}

Ball, R., Robin, A., \& Wu, S. (2003). The effect of international institutional factors on properties of accounting earnings. Journal of Accounting and Economics, 29(6), 417-434.

Barth, E., Landsman, R., \& Lang, H. (2004). International Accounting Standards and Accounting Quality. Research Paper, Stanford University Graduate School of Business.

Beke, J. (2010a). Business and Management Aspects of International Accounting Harmonization. International Journal of Business and Management, 5(12), 23-28.

Beke, J. (2010b). Accounting Management by International Standards. International Journal of Business and Management, 5(5), 36-43.

Beke, J. (2011a). International Accounting Standardization and Hungarian Practice. International Business Research, 4(1), 125-132.

Beke, J. (2011b). Accounting Globalization with International Standards. International Journal of Current Research, 3(10), 171-177.

Beke, J. (2011c). International Accounting Standardization Effects on Business Management. Global Journal of Management and Business Research, 11(6), 13-17.

Beke, J. (2011d). International Accounting Practice in Hungary. Regional and Business Research, 3(1), 9-21.

Burgstahler, D., Hail, L., \& Leuz, C. (2006). The importance of reporting incentives: earnings management in European private and public firms. International Business Review, 23(5), 48-69. 
Bushmann, R., \& Piotroski, J. (2006). Financial reporting incentives for conservative accounting: the influence of legal and political institutions. International Journal of Business and Management, 27, 148-161.

Callao, S., Jarne, J., \& Lainez, J. (2007). Adoption of IFRS in Spain: Effect on the comparability and relevance of financial reporting. Journal of International Accounting, Auditing and Taxation, 16(2), 148-178.

Chatterjee, R. (2006). Performance pricing and covenants in debt contracts in the UK. Judge Business School Working Paper 07, University of Cambridge.

Cordazzo, M. (2008). The impact of IAS/IFRS on accounting practices: evidence from Italian listed companies. Working Paper, Free University of Bozen-Bolzano, Italy.

Cormier, D., Demaria, S., Lapointe, P., \& Teller, R. (2009). First-Time Adoption of IFRS, Managerial Incentives, and Value-Relevance: Some French Evidence. Journal of International Accounting Research, 8(2), 1-22. http://dx.doi.org/10.2308/jiar.2009.8.2.1

Daske, H., \& Gebhardt, G. (2006). International Financial Reporting Standards and Experts, Perceptions of Disclosure Quality. Abacus, 42(3/4), 59-71.

Easley, D., \& Hara, M. (2004). Information and the Cost of Capital. The Journal of Finance, 9, 59-71.

Easton, P. (2006). Use of forecasts of earnings to estimate and compare cot of capital across regimes. Journal of Business Finance \& Accounting Research, 23(2), 49-71.

Epstein, B.J. (2009). The Economic effects of IFRS Adoption. The CPA Journal, 24(3), 26-31.

Guenther, A., \& Young, P. (2008). Financial Reporting Environments at International Capital Mobility. Journal of Accounting Researches, 8, 41-57.

Hung, M., \& Subramanyam, K. (2007). Financial statement effects of adopting international financial reporting standards: The case of Germany. Review of Accounting Studies, 12, 21-48. http://dx.doi.org/10.1007/s11142-007-9049-9

Iatridis, G., \& Rouvolis, S. (2010). The post-adoption effects of the implementation of International Financial Reporting Standards in Greece. Journal of International Accounting, Auditing and Taxation, 19(1), 55-65. http://dx.doi.org/10.1016/j.intaccaudtax.2009.12.004

Jermakovicz, K., Kinsey, P., \& Wulf, I. (2007). The Value Relevance of Accounting Income Reported by DAX-30, German Companies. Journal of International Financial Management \& Accounting, 18(3), 611-641.

Jones, S., \& Higgins, D. (2006). Australia's switch to international financial reporting standards: a perspective from account preparers, Journal of Accounting and Finance, 46(9), 629-652. http://dx.doi.org/10.1111/j.1467-629X.2006.00186.x

Lantto, M., \& Sahlström, P. (2009). Impact of International Financial Reporting Standard adoption on key financial ratios. Journal of Accounting and Finance, 49(5), 341-361. http://dx.doi.org/10.1111/j.1467-629X.2008.00283.x

La Porta, R. (1998). Law and Finance. The Journal of Political Economy, 106(9), 1113-1155. http://dx.doi.org/10.1086/250042

Leuz, C., \& Verrecchia, R.E. (2000). The economic consequences of increased disclosure. Journal of Accounting Research, 38, 91-124. http://dx.doi.org/10.2307/2672910

Nobes.G. (2007). A Survey of National Accounting Rules Benchmarked Against International Accounting Standards $\left(9^{\text {th }}\right.$ Edition). London.

Peng, S., \& Smith, L. (2010). Chinese GAAP and IFRS: An analysis of the convergence process. Journal of $\begin{array}{lllll}\text { International Accounting, Auditing and } & \text { 19-34. }\end{array}$ http://dx.doi.org/10.1016/j.intaccaudtax.2009.12.002

Smith, T. (1996). Accounting for Growth (2nd Ed.). London.

Swann, G. (2007). Horizontal and Vertical Product Innovation with standards. Nottingham University

Tarca, A. (2004). International convergence of accounting practices: Choosing between IAS and U.S.GAAP. Journal of International Financial Management and Accounting, 15, 60-91. http://dx.doi.org/10.1111/j.1467-646X.2004.00102.x

Tandeloo, B., \& Vanstraelen, A. (2005). Earnings management under German GAAP versus IFRS. European 
Accounting Review, 14(1), 155-180. http://dx.doi.org/10.1080/0963818042000338988

Temple, P. (2005). The Empirical Economics of Standards. DTI Economics Paper, 12, London.

Whittington, G. (2008). Harmonisation or discord? The critical role of IASB conceptual framework review. Journal of Accounting and Public Policy, 27(11), 495-502. http://dx.doi.org/10.1016/j.jaccpubpol.2008.09.006

Zeff, R. (2007). The Empirical Economics of Standards. DTI, Economics Paper, 19(12), London: Department of Trade and Industry. 